\title{
STUDIES ON WATERPROOFING WET-WHITE LEATHER
}

\author{
Vânia F.M. SILVA ${ }^{1 *}$, Mayerlys MONCADA ${ }^{1}$, António CRISPIM ${ }^{1}$, T. CRUZ², Filipe CRISPIM²,3 \\ ${ }^{1} \mathrm{CIETI} /$ ISEP - Centre of Innovation on Engineering and Industrial Technology / IPP School of Engineering, Rua Dr. António \\ Bernardino de Almeida, 831, 4200-072, Porto, Portugal \\ ${ }^{2}$ INDINOR - Indústrias Químicas, SA, Porto, Portugal \\ ${ }^{3} \mathrm{CTIC}$ - Technological Centre for Leather Industry, Alcanena, Portugal
}

Received: 13.03.2018

Accepted: 26.04 .2018

https://doi.org/10.24264/Ifj.18.2.10

\section{STUDIES ON WATERPROOFING WET-WHITE LEATHER}

ABSTRACT. Water resistance remains one of the more difficult goals to attain in leather manufacture. Although much is known from a scientific perspective, a problem persists when waterproofing wet-white leathers. The aim of this work was the study of the effect of different retanning agents on the waterproofing of wet-white leather produced by glutaraldehyde and syntan pre-tannage process. For that, a waterproofing process based in a waterproof fatliquor and a fluorocarbon based chemical, was tested applying different retanning resins, vegetable extracts and a dispersing agent to small leather pieces. Water resistance was evaluated by water absorption during 30 min in a static water bath at $25 \circ$ C. It was shown that retanning agents reduce water resistance when compared with the standard process without them. The reduction effect is stronger when a normal retanning acrylic resin, natural chestnut extract, and a dispersing agent are used. The water resistance reduction effect of tara extract, mimosa extract, quebracho extract, melamine resin, dicyandiamide resin and styrene maleic resin is not so evident. This work needs to be continued in order to evaluate other retanning chemicals, pass to a larger scale and then evaluate the water resistance by the common methods of the tanning industry.

KEY WORDS: leather, waterproof, wet-white

\section{STUDII PRIVIND IMPERMEABILIZAREA PIELII WET-WHITE}

REZUMAT. Rezistența la apă rămâne unul dintre obiectivele mai dificile de atins în procesul de fabricare a pieilor. Deși se cunosc multe din punct de vedere științific, o problemă persistă atunci când se realizează impermeabilizarea pieilor wet-white. Scopul acestei lucrări a fost de a studia efectul diferiților agenți de retăbăcire asupra impermeabilizării pieilor wet-white pretăbăcite cu glutaraldehidă și sintani. Pentru aceasta, a fost testat un procedeu de impermeabilizare bazat pe un agent de ungere rezistent la apă și un produs pe bază de fluorocarbon, prin testarea unor rășini de retăbăcire, extracte vegetale și un agent de dispersie pe bucăți mici de piele. Rezistența la apă a fost evaluată prin absorbția apei timp de 30 de minute într-o baie de apă statică la $25^{\circ} \mathrm{C}$. S-a demonstrat că agenții de retăbăcire reduc rezistența la apă în comparație cu procesul standard fără acestea. Efectul de reducere este mai puternic atunci când se utilizează o rășină acrilică de retăbăcire obișnuită, extract natural de castan și un agent de dispersie. Efectul de reducere a rezistenței la apă al extractelor de tara, mimosa, quebracho, al rășinii melaminice, al rășinii diciandiamide și al rășinii maleice stirenice nu este atât de evident. Această cercetare trebuie continuată pentru a evalua alte substanțe chimice de retăbăcire, pentru a trece la o scară mai mare și apoi pentru a evalua rezistența la apă prin metodele uzuale în industria de pielărie.

CUVINTE CHEIE: piele, impermeabil, wet-white

\section{ÉTUDES SUR L'IMPERMÉABILISATION DE LA PEAU WET-WHITE}

RÉSUMÉ. La résistance à l'eau reste l'un des objectifs les plus difficiles à atteindre dans la fabrication du cuir. Bien que beaucoup de choses soient connues d'un point de vue scientifique, un problème persiste lors de l'imperméabilisation des peaux wet-white. Le but de cet article a été l'étude de l'effet de différents agents de retannage sur l'imperméabilisation des peaux wet-white obtenues par pré-tannage au glutaraldéhyde et aux syntans. Pour cela, un procédé d'imperméabilisation à base d'un agent graisse résistant à l'eau et d'un produit chimique à base de fluorocarbone a été testé en appliquant différentes résines de retannage, des extraits végétaux et un agent dispersant sur de petits morceaux de peau. La résistance à l'eau a été évaluée par l'absorption d'eau pendant 30 minutes dans un bain d'eau statique à $25^{\circ} \mathrm{C}$. II a été montré que les agents de retannage réduisent la résistance à l'eau par rapport au processus standard qui ne les utilise pas. L'effet de réduction est plus fort lorsqu'une résine acrylique de retannage classique, un extrait naturel de châtaigne et un agent de dispersion sont utilisés. L'effet de réduction de la résistance à l'eau de l'extrait de tara, de l'extrait de mimosa, de l'extrait de quebracho, de la résine de mélamine, de la résine dicyandiamide et de la résine styrène maléique n'est pas si évident. Ce travail doit être poursuivi afin d'évaluer d'autres produits chimiques de retannage, passer à plus grande échelle et ensuite évaluer la résistance à l'eau par les méthodes courantes de l'industrie du cuir. MOTS CLÉS: cuir, imperméable, wet-white

* Correspondence to: Vânia F.M. SILVA, CIETI/ISEP - Centre of Innovation on Engineering and Industrial Technology/IPP School of Engineering, Rua Dr. António Bernardino de Almeida, 831, 4200-072, Porto, Portugal, vfmsi@isep.ipp.pt. 


\section{INTRODUCTION}

Water resistance remains one of the more difficult goals to attain in leather manufacture. Although much is known from a scientific perspective, a problem persists when waterproofing wet-white leathers. A survey of commercially available chemicals is found on the market for a successful waterproofing of wet-blue leather [1]. The performance of these chemicals, when used in wet-white leather, is not the same because the substrate is very different. The demand of chromium free leathers has increased last years and the need to improve the water resistance of these leathers gains importance.

There are many factors that influence the waterproofness of leather, mainly the process and chemicals used in leather manufacture: surfactants, tanning agents, retanning and fatliquoring agents, and finishing agents.

Degreasing and soaking of hides must be carried out carefully with the minimal amount of surfactants. Complete penetration during neutralization is very important. The longer the neutralization time the better for thicker substrates. A good neutralization will allow deeper penetration of the hydrophobic fatliquor. The addition of waterproofing fatliquor is recommended to be done in two or more portions, the first to the retanning bath before the retanning agents and the other in a new bath after retanning and dyeing [2]. Fatliquoring agent plays an important role in the waterproofing of leather, the deeper the fatliquoring the better will be the results for waterproofing [3].

The main process used for chrome-free leathers is a glutaraldehyde and syntan tannage. This tannage can cause some problems to the waterproofing process because glutaraldehyde blocks the majority of cationic collagen groups and chromium absence prevents the fixation of hydrophobic agents inside the substrate because of the missing cationic valences [4].

Some authors give new ideas and suggest new ways to improve the water resistance of wet-white leather, from fluorocarbons to plasma technology [5-8].

In order to know more about the water resistance of wet-white leather, the authors intended to begin a work researching some practical aspects of the waterproofing process.
This work is the first part of the research and has been done to evaluate the effect of retanning agents in a waterproofing process based in a known waterproof fatliquor from Atlas Refinery and a fluorocarbon based chemical, Indinol FW, developed by INDINOR, a chemical company located in Portugal.

\section{EXPERIMENTAL}

\section{Materials and Methods}

The raw material used in this work was wet-white leather prepared by INDINOR, using a glutaraldehyde (Fortan GL) and syntan (Inditan VOC liq.) pre-tannage. The wet-white leather, thus prepared, with a shrinkage temperature of 78 ㅇ, was shaved to a thickness of $1.4 \mathrm{~mm}$ and subjected to a waterproofing process according to Table 1 to test the effect of different retanning agents. For all the trials, small pieces of wetwhite were used, about $80 \mathrm{~g}$, always from the same zone near the back-bone. The chemicals used were all obtained from INDINOR, and the trials were carried out using small laboratory drums at ISEP, with temperature and speed control. Chemical quantities were based on the weight of shaved wet-white hide pieces used.

After this process the hide pieces were left to rest for 48 hours, squeezed, dried and stacked. Then, the water resistance was evaluated according to the next method: a small piece with about 4 to $6 \mathrm{~g}$ was cut, weighed, poured into static water at $25 \circ \mathrm{C}$ for $30 \mathrm{~min}$, removed from water and weighed again. The water absorption was calculated as the percentage of weight increase based on the initial weight.

Several trials were carried out to evaluate the effect of different retanning agents on the waterproof effect against a standard process with no retanning agent and where the running time of waterproof fatliquor was $180 \mathrm{~min}$.

\section{RESULTS AND DISCUSSIONS}

After stacking, the hide pieces were evaluated for the water resistance, and the results are presented in Figures 1, 2 and 3.

Figure 1 shows a reduction in water resistance when resins are applied, with a stronger effect for acrylic resin, comparing to the standard process. 
Table 1: Waterproofing process

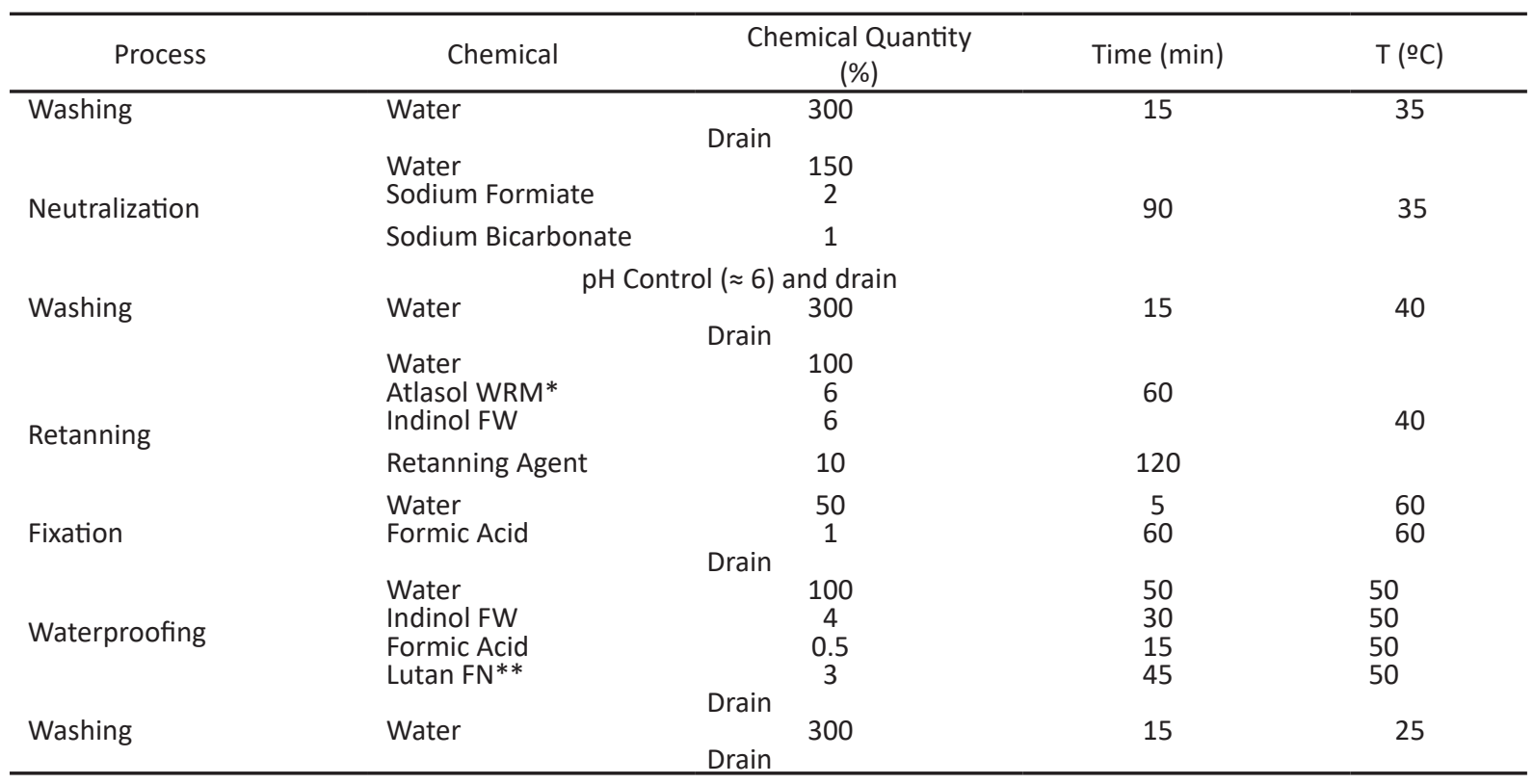

*Waterproofing fatliquor from Atlas Refinery;

** Aluminium salt from BASF.

After this process the hide pieces were left to rest for 48 hours, squeezed, dried and stacked. Then, the water resistance was evaluated according to the next method: a small piece with about 4 to $6 \mathrm{~g}$ was cut, weighed, poured into static water at $25 \circ \mathrm{C}$ for $30 \mathrm{~min}$, removed from water and weighed again. The water absorption was calculated as the percentage of weight increase based on the initial weight.

Several trials were carried out to evaluate the effect of different retanning agents on the waterproof effect against a standard process with no retanning agent and where the running time of waterproof fatliquor was $180 \mathrm{~min}$. Table 2 shows the trials description.

Table 2: Retanning agents applied in the different trials

\begin{tabular}{cll}
\hline Trial & & Retanning Agent \\
\hline T1 & No Retanning agent added & \\
T2 & Fortan A40 (acrylic resin) \\
T3 & Fortan CM/N ECO (melamine resin) \\
T4 & Fortan DC (dicyanodiamide resin) \\
T5 & Fortan SML (styrene maleic resin) \\
T6 & Natural Chestnut extract \\
T7 & Tara extract \\
T8 & Mimosa extract \\
T9 & Quebracho extract \\
T10 & Natural Chestnut extract + 2\% Inditan RS (dispersing agent) \\
T11 & Tara extract + 2\% Inditan RS \\
T12 & Mimosa extract + 2\% Inditan RS \\
T13 & Quebracho extract + 2\% Inditan RS \\
\hline
\end{tabular}

Figure 2 shows a reduction in water resistance when vegetable extracts are applied, with a stronger effect for natural chestnut, comparing to the standard process.
Figure 3 shows a higher reduction in water resistance when a dispersing agent is used to improve the penetration of vegetable extracts, comparing to the standard process. 


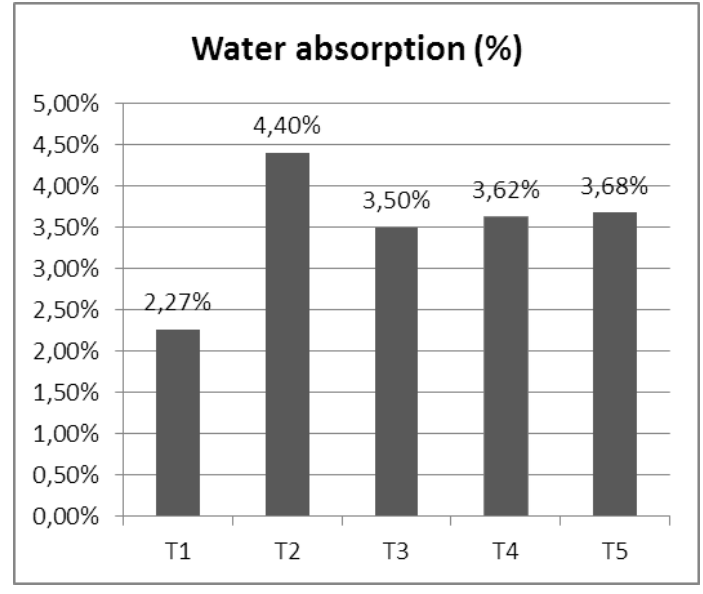

Figure 1. Water absorption for retannage with resins

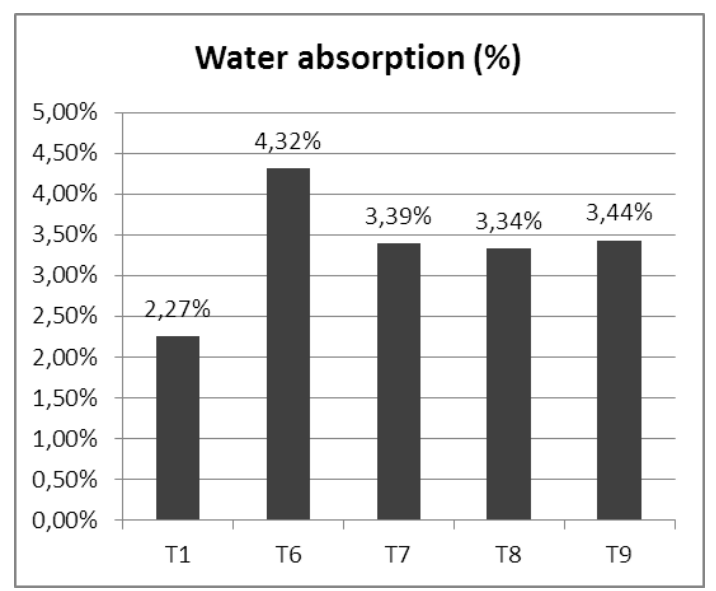

Figure 2. Water absorption for retannage with vegetable extracts

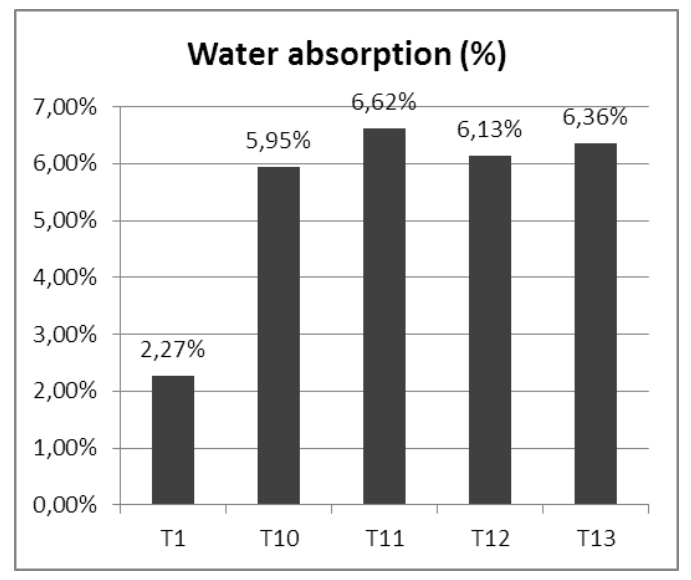

Figure 3. Water absorption for retannage with vegetable extracts and dispersing agent
As we can see from Figures 1, 2 and 3, the effect of retanning agents leads to a reduction in water resistance, mainly when chemicals with dispersing properties are used.

\section{CONCLUSIONS}

The aim of this work was the study of the effect of retanning agents on the water resistance of leather based in wet-white tanning.

It was shown that water resistance is affected by retanning agents, with more evidence for the acrylic resin, for natural chestnut extract and mainly for dispersing agents.

In the future, it will be important to test this process with other retanning chemicals, pass to a larger scale and then evaluate the water resistance by the common methods of the tanning industry. Another important work is the comparison of this waterproofing process applied in wet-white versus wet-blue.

\section{Acknowledgements}

The authors would like to acknowledge QREN Portuguese National Program and IAPMEI for the support of the project HYDROSYST, and also to ISEP for the availability of small drums.

\section{REFERENCES}

1. Hudson, A., Leather, 2000, 47-48.

2. Vitalini, M., Behr, D., Leather, 1997, 38-40.

3. Zhaoyang, L., Haojun, F., Yan, L., Bi, S., J Soc Leath Tech Ch, 2008, 97, 107-113.

4. Meyer, M., Leather International, 2012, 26-28.

5. Segura, R., Izquierdo, F., Canicio, R., Lederpiel, 2003, 50-55.

6. Leather Business Unit, World Leather, 2002, 37-40.

7. Meyndt, R., Germann, H.P., Cuoio Pelli Materie Concianti, 2006, 321-330.

8. Hansel, R., Stoll, M., Cuoio Pelli Materie Concianti, 2007, 7-18.

(C) 2018 by the author(s). Published by INCDTPICPI, Bucharest, RO. This is an open access article distributed under the terms and conditions of the Creative Commons Attribution license (http:// creativecommons.org/licenses/by/4.0/). 